\section{TRENDS IN WORLD MILITARY EXPENDITURE, 2015}

\author{
SAM PERLO-FREEMAN, AUDE FLEURANT, PIETER WEZEMAN AND \\ SIEMON WEZEMAN
}

Global military expenditure in 2015 was an estimated \$1676 billion, representing an increase of about 1.0 per cent in real terms from $2014 .{ }^{1}$ Total expenditure was equivalent to 2.3 per cent of global gross domestic product (GDP). This is the first increase in world military spending since 2011. The total rose continuously for 13 years from 1998 to 2011, before decreasing slightly between 2011 and 2014 (see figure 1).

The SIPRI Military Expenditure Database, available at <http://www.sipri. org/databases/milex/>, was updated on 5 April 2016 to include new data on military expenditure in 2015. This Fact Sheet highlights regional and national trends in 2015 and between 2006 and 2015, as revealed by the new data.

Military expenditure in North America and Western Europe fell again in 2015, but at a slower pace than in previous years. Military expenditure

${ }^{1}$ All totals exclude figures for certain countries for which it is judged that reasonable estimates cannot be made due to long-term lack of data. These countries are Cuba, Eritrea, North Korea, Somalia, Sudan, Syria, Turkmenistan and Uzbekistan. Unless otherwise stated, dollar figures for national, regional or global military spending in 2015 refer to spending at current prices and exchange rates-i.e. converted from national currency to US dollars at the average market or official exchange rate for 2015. Figures for percentage changes between 2 years, unless otherwise stated, are given in 'real terms'-i.e. adjusted for inflation. The SIPRI Military Expenditure Database includes figures for each country and region in constant (2014) US dollars, which is the basis for the real-terms calculations. This means that local currency figures are first adjusted for inflation in each country to express them in 2014 prices and then they are converted into US dollars at the average market or official exchange rate for 2014

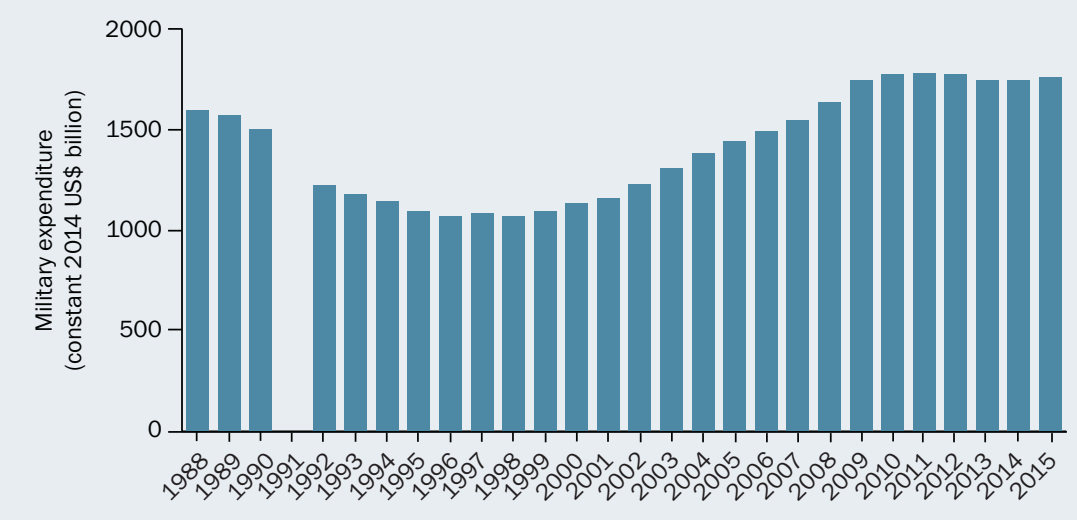

Figure 1. World military expenditure, 1988-2015

Note: The totals are based on the data on 172 states in the SIPRI Military Expenditure Database, <http://www.sipri.org/databases/milex/>. The absence of data for the Soviet Union in 1991 means that no total can be calculated for that year.

\section{KEY FACTS}

- World military expenditure was \$1676 billion in 2015.

- Total global spending rose by 1.0 per cent in real terms in 2015 , the first increase since 2011.

- The five biggest spenders in 2015 were the USA, China, Saudi Arabia, Russia and the UK.

- Military expenditure increased in Asia and Oceania, Central and Eastern Europe, and in those countries in the Middle East for which data is available.

- Military spending decreased in North America, Western Europe, Latin America and the Caribbean, and Africa.

- Military expenditure in the USA fell by 2.4 per cent to $\$ 596$ billion-a slower rate of decline than in recent years, mainly due to steps taken by the US Congress to mitigate the impact of the spending reductions imposed by the 2011 Budget Control Act.

- The decline in military spending in Western Europe slowed to 1.3 per cent, while countries in Central Europe increased spending by 13 per cent, largely prompted by fears of Russian aggression following the Ukraine crisis.

- The fall in world oil prices led to cuts in military spending in several oil revenue-dependent countries that had previously made rapid increases. Othersincluding Russia and Saudi Arabia-continued to boost spending, but Russia is planning cuts in 2016, and reductions are also likely in Saudi Arabia. 


\section{EMBARGOED UNTIL 5 APRIL 2016, 00:01 AM CET}

Table 1. The 15 countries with the highest military expenditure in 2015

Spending figures are in US\$, at current prices and exchange rates. Figures for changes are calculated from spending figures in constant (2014) prices. Figures may not add up to displayed totals due to the conventions of rounding.

\begin{tabular}{|c|c|c|c|c|c|c|c|}
\hline \multicolumn{2}{|c|}{ Rank } & \multirow[b]{2}{*}{ Country } & \multirow{2}{*}{$\begin{array}{l}\text { Spending, } \\
2015 \text { (\$ b.) }\end{array}$} & \multirow{2}{*}{$\begin{array}{l}\text { Change, } \\
2006-15 \\
(\%)\end{array}$} & \multirow{2}{*}{$\begin{array}{l}\text { World } \\
\text { share } \\
2015(\%)\end{array}$} & \multicolumn{2}{|c|}{$\begin{array}{l}\text { Spending } \\
\text { as a } \\
\text { share of GDP } \\
(\%)^{b}\end{array}$} \\
\hline 2015 & $2014^{a}$ & & & & & 2015 & 2006 \\
\hline 1 & 1 & USA & 596 & -3.9 & 36 & 3.3 & 3.8 \\
\hline 2 & 2 & China & [215] & 132 & {$[13]$} & [1.9] & {$[2.0]$} \\
\hline 3 & 4 & Saudi Arabia & 87.2 & 97 & 5.2 & 13.7 & 7.8 \\
\hline 4 & 3 & Russia & 66.4 & 91 & 4.0 & 5.4 & 3.5 \\
\hline 5 & 6 & UK & 55.5 & -7.2 & 3.3 & 2.0 & 2.2 \\
\hline 6 & 7 & India & 51.3 & 43 & 3.1 & 2.3 & 2.5 \\
\hline 7 & 5 & France & 50.9 & -5.9 & 3.0 & 2.1 & 2.3 \\
\hline 8 & 9 & Japan & 40.9 & -0.5 & 2.4 & 1.0 & 1.0 \\
\hline 9 & 8 & Germany & 39.4 & 2.8 & 2.4 & 1.2 & 1.3 \\
\hline 10 & 10 & South Korea & 36.4 & 37 & 2.2 & 2.6 & 2.5 \\
\hline 11 & 11 & Brazil & 24.6 & 38 & 1.5 & 1.4 & 1.5 \\
\hline 12 & 12 & Italy & 23.8 & -30 & 1.4 & 1.3 & 1.7 \\
\hline 13 & 13 & Australia & 23.6 & 32 & 1.4 & 1.9 & 1.8 \\
\hline 14 & 14 & $\mathrm{UAE}^{c}$ & {$[22.8]$} & 136 & {$[1.4]$} & {$[5.7]$} & {$[3.2]$} \\
\hline 15 & 15 & Israel & 16.1 & 2.6 & 1.0 & 5.4 & 7.5 \\
\hline \multicolumn{2}{|c|}{ Total top 15} & & 1350 & & 81 & & \\
\hline \multicolumn{2}{|c|}{ World total } & & 1676 & 19 & 100 & 2.3 & 2.3 \\
\hline
\end{tabular}

[] = SIPRI estimate; GDP = gross domestic product; UAE = United Arab Emirates.

${ }^{a}$ Rankings for 2014 are based on updated military expenditure figures for 2014 in the current edition of the SIPRI Military Expenditure Database. They may therefore differ from the rankings for 2014 given in the SIPRI Yearbook 2015 and in other SIPRI publications in 2015.

$b$ The figures for military expenditure as a share of gross domestic product (GDP) are based on estimates of 2015 GDP from the International Monetary Fund (IMF) World Economic Outlook Database, Oct. 2015.

${ }^{c}$ The figures for the UAE are for 2014, as no data is available for 2015. The percentage change is from 2006 to 2014. decreased in Africa, breaking an 11-year trend of spending increases. Spending in Latin America and the Caribbean also declined. In contrast, spending in Central and Eastern Europe continued to rise sharply. There were also substantial increases in Asia and Oceania and in those countries in the Middle East for which data is available.

The sharp fall in oil prices that began in late 2014 has led to an abrupt reduction in military spending in a number of countries that had increased their levels of spending in recent years. These include Angola, Chad, Ecuador, Kazakhstan, Oman, South Sudan and Venezuela. However, other oil revenue-dependent countries continued to increase spending, including Algeria, Azerbaijan, Russia and Saudi Arabia, although in the latter two cases spending is expected to fall in 2016.

\section{THE TOP 15 MILITARY SPENDERS IN 2015}

There was no change in the countries that comprised the top 15 military spenders in 2015 compared with 2014, although there were some changes in order (see table 1).

The United States, with total expenditure of $\$ 596$ billion, remains by far the world's largest military spender, at nearly three times the level of China, which is ranked second. Nonetheless, US military expenditure continued to decline in 2015 but at its slowest annual rate since 2011 ( -2.4 per cent). Projections for 2016 indicate that US military spending will remain roughly constant in real terms. Since its most recent peak in 2010, US military expenditure has decreased by 21 per cent, due to the withdrawal of most of its troops from Afghanistan and Iraq, and the impact of the 2011 Budget Control Act (BCA). The BCA imposed across-the-board cuts on all US federal executive departments, but its impact has been mitigated by short-term budget deals in 2014 and 2015, including measures to boost military expenditure. Despite the downward trend in US spending over the past five years, the USA's share of world military expenditure remains high, at 36 per cent (see figure 2). China stayed in second place, with spending rising by 7.4 per cent in 2015 , although the rate of increase is beginning to slow in line with weakening economic growth. ${ }^{2}$

\footnotetext{
${ }^{2}$ SIPRI's military expenditure estimates for China have been revised downwards since the previous edition of the SIPRI Military Expenditure Database published in 2015.
} 


\section{EMBARGOED UNTIL 5 APRIL 2016, 00:01 AM CET}

Saudi Arabia overtook Russia to become the third-largest spender, mainly due to the fall in the value of the rouble. Despite additional spending by Saudi Arabia on military operations in Yemen, its annual rate of growth also slowed (5.7 per cent) due to the sharp fall in the price of oil. The fall in oil prices meant that Russia's increase of 7.5 per cent in 2015 was considerably lower than projected in its budget. Moreover, the 2016 budget shows a reduction in military spending. Nevertheless, Saudi Arabia and Russia registered the highest levels of military expenditure as a share of GDP since 1990 (13.7 per cent and 5.4 per cent, respectively).

The drop in the value of the euro was a major factor behind the United Kingdom climbing to fifth position above France, which fell to seventh, and Japan overtaking Germany to move into eighth place. Among other top 15 countries in 2015, the largest growth was by Australia (7.8 per cent), while the biggest decrease was by Italy ( -9.9 per cent). There were also modest falls for France, Brazil and Israel, and small increases

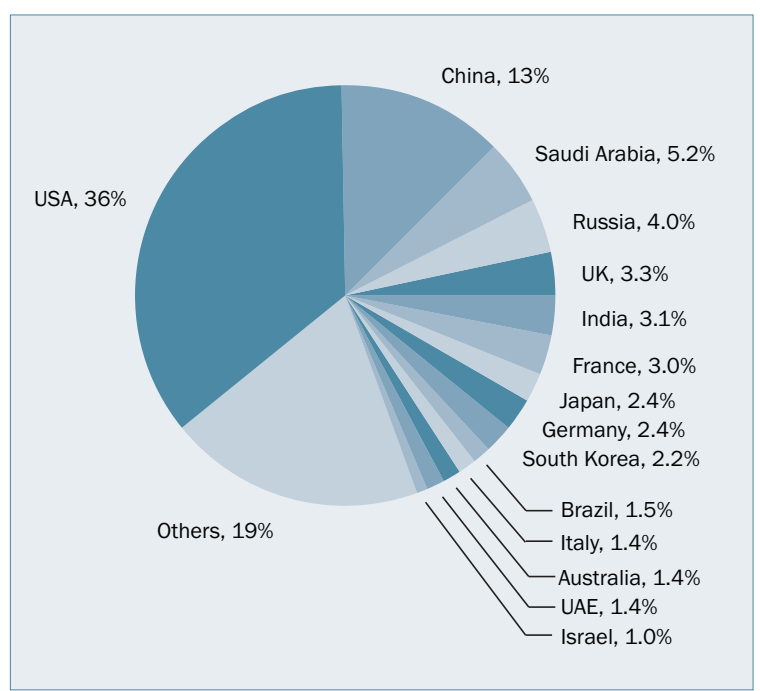

Figure 2. The share of world military expenditure of the 15 states with the highest spending in 2015 for Germany and South Korea.

\section{REGIONAL TRENDS}

\section{Asia and Oceania}

Military spending in Asia and Oceania rose by 5.4 per cent in 2015 and by 64 per cent between 2006 and 2015, reaching $\$ 436$ billion in 2015 at current prices and exchange rates (see table 2). China had by far the highest military expenditure in the region: an estimated $\$ 215$ billion, or 49 per cent of regional spending. This was more than four times that of India, which was the region's second-largest spender.

Almost all countries in the region increased their spending between 2006 and 2015. However, the level of growth varied widely: Afghanistan, New Zealand and Singapore each grew by around 9 per cent compared with China and Indonesia which grew 132 and 150 per cent, respectively. Only Fiji recorded a significant decrease between 2006 and 2015 (-23 per cent). Japan's spending was down by 0.5 per cent over the period.

Heightened tensions with China over the South China Sea are reflected in substantial growth in military expenditure in 2015 by Indonesia (16 per cent), the Philippines ( 25 per cent) and Viet Nam (7.6 per cent). Japan also began to increase spending in 2015 after years of decline, signalling rising threat perceptions from both China and North Korea.

India's military spendingin 2015 was $\$ 51.3$ billion, an increase of 0.4 per cent. India plans to increase military expenditure by about 8 per cent (in real terms) in 2016, partly to fund many large ongoing and planned procurement programmes.

Afghanistan reduced spending by 19 per cent to $\$ 199$ million in 2015, which is perhaps surprising as Afghan forces have assumed responsibility for security following the withdrawal of most foreign troops. However, Afghanistan's military is

Table 2. Military expenditure in Asia and Oceania

\begin{tabular}{|c|c|c|c|}
\hline & \multirow{2}{*}{$\begin{array}{l}\text { Spending, } \\
2015 \text { (\$ b.) }\end{array}$} & \multicolumn{2}{|c|}{ Change (\%) ${ }^{a}$} \\
\hline & & $2014-15$ & $2006-15$ \\
\hline Asia and Oceania & 436 & 5.4 & 64 \\
\hline $\begin{array}{l}\text { Central and South } \\
\text { Asia }^{b}\end{array}$ & 68.0 & 0.9 & 44 \\
\hline East Asia & 302 & 5.7 & 75 \\
\hline Oceania & 25.8 & 7.7 & 30 \\
\hline South East Asia & 39.7 & 8.8 & 57 \\
\hline
\end{tabular}

${ }^{a}$ Changes are in real terms.

${ }^{b}$ Total excludes Turkmenistan and Uzbekistan. 


\section{EMBARGOED UNTIL 5 APRIL 2016, 00:01 AM CET}

mainly funded by military aid from foreign donors, which amounted to $\$ 5.35$ billion in 2015 .

\section{Europe}

European military expenditure increased by 1.7 per cent in 2015 to $\$ 328$ billion, 5.4 per cent higher than in 2006 (see table 3). Spending in Western and Central Europe was $\$ 253$ billion, down 0.2 per cent on 2014 and down 8.5 per cent compared with 2006 (see figure 3). Expenditure in Eastern Europe was \$74.4 billion, up 7.5 per cent on 2014 and up 90 per cent compared with 2006.

There were signs in 2015 that the austerity-driven decline in military spending in Western and Central Europe that has held sway since 2010 may be coming to an end. While military spending in Western Europe continued to fall (by 1.3 per cent in 2015), for the first time since 2009 the number of countries in the subregion that increased expenditure was higher than the number of those that reduced spending. The three biggest spenders in Western Europe-the UK, France and Germany-have all signalled a growth in spending in coming years.

Military expenditure in Central Europe rose for a second consecutive year (by 13 per cent), with a clear majority of countries increasing spending. Total expenditure in 2015 was slightly higher than its previous peak in 2007. Growth in military spending was most apparent in the countries bordering Russia or Ukraine, reflecting the escalating fear of a threat from Russia. Poland boosted spending by 22 per cent to $\$ 10.5$ billion in line with its 10 -year $\$ 40$ billion military modernization plan, and military spending reached 2.2 per cent of its GDP in 2015. Romania increased spending by 11 per cent to $\$ 2.5$ billion and declared its intention to raise its military burden from the current 1.4 per cent of GDP to the North Atlantic Treaty Organization (NATO) target of 2 per cent by 2017. Romania's initial defence budget for 2016 shows a further rise of 53 per cent. Meanwhile, Slovakia's spending grew by 17 per cent, and the Baltic states-Estonia, Latvia and Lithuania-increased military expenditure by 6.6,14 and 33 per cent, respectively. Overall spending by NATO's European members (including Turkey) was $\$ 250$ billion, down 0.3 per cent compared with 2014.

In Eastern Europe, Russia's military spending in 2015 was $\$ 66.4$ billion, up 7.5 per cent from 2014, and up 91 per cent compared with 2006. The economic crisis related to falling oil and gas prices, coupled with economic sanctions, dramatically reduced Russian Government revenues. The government was forced to cut budgeted spending in all departments in early 2015. Actual military expenditure was 3 per cent lower in 2015 than originally planned.

Table 3. Military expenditure in Europe

\begin{tabular}{|c|c|c|c|}
\hline & \multirow{2}{*}{$\begin{array}{l}\text { Spending, } \\
2015 \text { (\$ b.) }\end{array}$} & \multicolumn{2}{|c|}{ Change $(\%)^{a}$} \\
\hline & & 2014-15 & $2006-15$ \\
\hline Europe & 328 & 1.7 & 5.4 \\
\hline Eastern Europe & 74.4 & 7.5 & 90 \\
\hline $\begin{array}{l}\text { Western and } \\
\text { Central Europe }\end{array}$ & 253 & -0.2 & -8.5 \\
\hline
\end{tabular}

However, budget cuts for other departments were closer to 10 per cent. In reaction to further falls in the price of oil, the planned defence budget for 2016 is about 9 per cent lower in real terms than spending in 2015.

Ukraine's military expenditure in 2015 was $\$ 3.6$ billion, an increase of 10 per cent compared with 2014. With fighting in eastern Ukraine continuing in 2015, the military budget was revised upwards several times during the year. Ukraine's military spending has risen by 61 per cent since 2006, including a 34 per cent increase since 2013 alone. 
EMBARGOED UNTIL 5 APRIL 2016, 00:01 AM CET

In the South Caucasus, Azerbaijan spent $\$ 3.0$ billion in 2015, up 165 per cent compared with 2006. Despite the fall in oil prices, Azerbaijan's military expenditure was 8.0 per cent higher in 2015 than in 2014 due to rising tensions in its conflict with Armenia over Nagorno-Karabakh. Azerbaijan is highly dependent on oil revenues and its preliminary 2016 budget indicates reductions in military spending. Armenia's military expenditure in 2015 (\$447 million) was substantially lower than that of its neighbour, but was up 7.7 per cent from 2014 and up 71 per cent compared with 2006.

\section{The Middle East}

SIPRI is not publishing an estimate for the Middle East for 2015 as data for 2015 is unavailable for

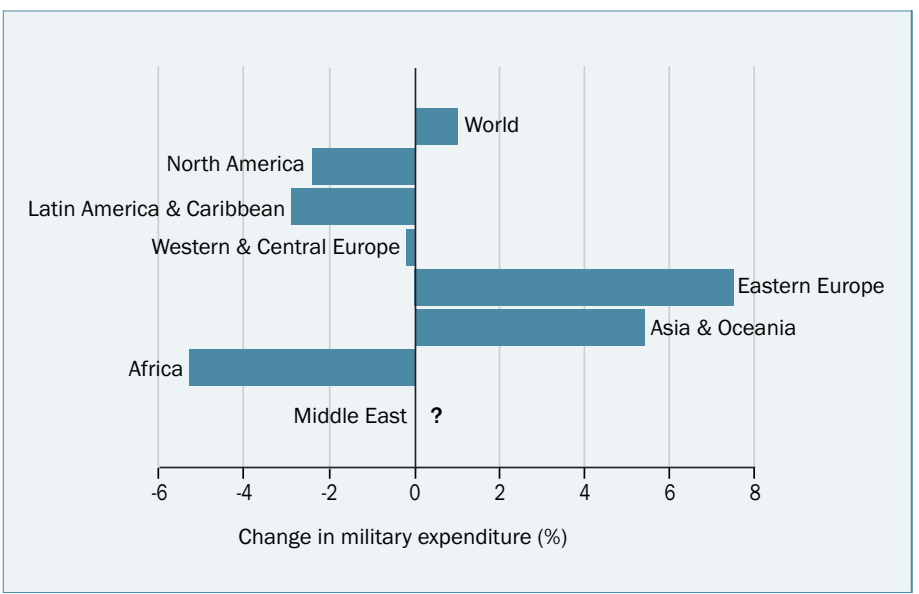

Figure 3. Changes in military expenditure, by region, 2014-15 Note: Military expenditure data for the Middle East in 2015 is highly uncertain. An estimate for the Middle East is included in the estimated world total. several countries. Regional totals compiled by SIPRI often include estimates when data for certain countries is missing. However, this approach would have produced highly uncertain data for the Middle East in 2015 given the large number of countries for which information is not available, the size of their respective share of total regional spending and the volatile regional situation. For those countries for which data is available, military expenditure increased by 4.1 per cent in $2015 .^{3}$

Saudi Arabia is by far the largest military spender in the region, with an estimated $\$ 87.2$ billion in 2015. Its spending doubled between 2006 and 2015; however, its military expenditure figures are uncertain, as only the initial budget for 'defence and security' has been published. Total actual annual government spending has been significantly higher than budgeted for every year since 2010. It was reported that 17 per cent of total government overspending in 2015 came from a $\$ 5.3$ billion increase in military and security expenditure due to the Saudi military intervention in Yemen. The fall in oil prices has led to a reduction in the defence and security budget for 2016, although provision for substantial 'budget support' has been made to allow flexibility in the overall budget; some of this support may be used for military spending.

The largest increase in the region-and indeed the world-between 2006 and 2015 was by Iraq. It has rebuilt its armed forces in the aftermath of the US-led invasion and subsequent withdrawal, and is now embroiled in a war with the Islamic State. Iraq's military spending was $\$ 13.1$ billion in 2015 , up 35 per cent from 2014, and up 536 per cent from 2006 (see table 6 on page 7).

Iran's military expenditure decreased by 30 per cent between 2006 and 2015 , with spending in 2015 standing at $\$ 10.3$ billion. The main fall occurred in 2012-13 after the European Union imposed a series of economic and financial sanctions against Iran in January 2012. The lifting of EU (and some US sanctions) in January 2016 is expected to boost the Iranian economy and may lead to a rise in military expenditure.

\footnotetext{
${ }^{3}$ The countries with missing data for 2015 are Kuwait, Qatar, Syria, the United Arab Emirates and Yemen.
} 


\section{EMBARGOED UNTIL 5 APRIL 2016, 00:01 AM CET}

Table 4. Military expenditure in the Americas

\begin{tabular}{lccl} 
& Spending, & \multicolumn{2}{l}{ Change (\%) ${ }^{a}$} \\
\cline { 4 - 4 } & $2015(\$ \mathrm{~b})$. & $2014-15$ & $2006-15$ \\
\hline Americas & 678 & -2.5 & -0.8 \\
$\begin{array}{l}\text { Central America } \\
\text { and Caribbean }\end{array}$ & 9.5 & 3.7 & 84 \\
$\begin{array}{l}\text { North America } \\
\text { South America }\end{array}$ & 611 & -2.4 & -3.8 \\
\hline
\end{tabular}

${ }^{a}$ Changes are in real terms.

\section{Latin America and the Caribbean}

Military expenditure in Latin America and the Caribbean fell by 2.9 per cent in 2015 to $\$ 67.0$ billion, although this is still 33 per cent higher than in 2006. In South America military spending was $\$ 57.6$ billion, down 4.0 per cent from 2014 but up 27 per cent compared with 2006 (see table 4). In Central America and the Caribbean total military spending was $\$ 9.5$ billion, up 3.7 per cent from 2014 and up by 84 per cent from 2006.

The fall in South American spending was the result of a 64 per cent cut in the military budget by Venezuela, which has been hit by a severe economic crisis, largely as a result of the fall in the price of oil. Real GDP was projected to go down by 10 per cent in 2015, with overall government revenue decreasing by 63 per cent in real terms. However, as inflation was approximately 159 per cent in 2015, actual spending may have been higher than budgeted, so the figures for Venezuela should be treated with caution.

Ecuador-which has had high levels of military expenditure for several years funded by surging oil revenues-cut spending by 11 per cent in 2015 . Brazil's military spending also fell by 2.2 per cent as the country experienced economic recession. However, several other South American countries in a stronger economic position boosted their military spending significantly in 2015, including Colombia, Guyana, Paraguay, Peru and Uruguay.

In Central America, military spending trends are driven by the extreme levels of violent organized crime, as military forces have become increasingly involved in combating drug gangs and cartels. Mexico's military spending continued to rise in 2015 (by 3.6 per cent) reaching $\$ 7.7$ billion, 92 per cent higher than in 2006. Military expenditure in Honduras-which has the world's second-highest homicide rate-increased by 186 per cent between 2006 and 2015, the largest rise in the subregion. Honduras's military spending includes some of the proceeds of a special 'population-security tax' imposed in 2012 to provide additional funds to the military, police and intelligence agencies.

\section{Africa}

Military expenditure in Africa fell by 5.3 per cent in 2015, reaching an estimated $\$ 37.0$ billion, following 11 continuous years of rising spending (see table 5). ${ }^{4}$ Total spending in 2015 remained 68 per cent
Table 5. Military expenditure in Africa

\begin{tabular}{llll}
\hline & \multicolumn{2}{l}{ Spending, } & \multicolumn{2}{c}{ Change $(\%)^{a}$} \\
\cline { 3 - 4 } & $2015(\$$ b.) & $2014-15$ & $2006-15$ \\
\hline Africa $^{b}$ & $(37.0)$ & -5.3 & 68 \\
North Africa & $(17.9)$ & 2.1 & 148 \\
$\begin{array}{l}\text { Sub-Saharan } \\
\text { Africa }\end{array}$ & 19.1 & -11 & 30 \\
\hline
\end{tabular}

()$=$ uncertain estimate.

${ }^{a}$ Changes are in real terms.

${ }^{b}$ Total excludes Eritrea and Sudan. higher than in 2006. Military spending in North Africa was $\$ 17.9$ billion, up by 2.1 per cent from 2014 and up 148 per cent compared with 2006, while spending in sub-Saharan Africa was $\$ 19.1$ billion, down 11 per cent from 2014, but still 30 per cent higher than in 2006.

The trend in sub-Saharan Africa was dominated by a 42 per cent fall in spending by Angola due to decreasing oil revenues,

\footnotetext{
${ }^{4}$ This total excludes Eritrea and Sudan. Due to the lack of available data, SIPRI was unable to make reliable estimates for these countries for inclusion in the regional total.
} 
EMBARGOED UNTIL 5 APRIL 2016, 00:01 AM CET

Table 6. The biggest increases and decreases in military spending, 2006-15

Spending figures are in US\$ million, at current prices and exchange rates. Figures for changes are calculated from spending figures in constant (2014) prices. Countries are ordered by actual \% increase or decrease.

\begin{tabular}{|c|c|c|c|c|c|}
\hline Country & $\begin{array}{l}\text { Military spending, } 2015 \\
\text { (\$ m.) }\end{array}$ & $\begin{array}{l}\text { Increase (\%), } \\
2006-15\end{array}$ & Country & $\begin{array}{l}\text { Military spending, } 2015 \\
\text { (\$ m.) }\end{array}$ & $\begin{array}{l}\text { Decrease (\%), } \\
2006-15\end{array}$ \\
\hline Iraq & 13121 & 536 & Venezuela & (5 265) & $(-77)$ \\
\hline Gambia & 12.5 & 380 & Slovenia & 407 & -37 \\
\hline Congo, Republic of ${ }^{a}$ & 705 & 287 & Latvia & 286 & -37 \\
\hline Argentina & $(5475)$ & $(240)$ & Greece & 5083 & -35 \\
\hline Ghana & 180 & 227 & Czech Republic & 1778 & -35 \\
\hline Libya $^{a}$ & 3289 & 225 & Hungary & 1023 & -31 \\
\hline Algeria & 10413 & 210 & Georgia & 327 & -31 \\
\hline Namibia & 554 & 200 & Italy & 23840 & -30 \\
\hline Honduras & 324 & 186 & Iran & 10265 & -30 \\
\hline Mali & 309 & 185 & Ethiopia & 423 & -30 \\
\hline Zimbabwe & 377 & (184) & Bulgaria & 661 & -27 \\
\hline Azerbaijan & 3021 & 165 & Sierra Leone & 42.2 & -24 \\
\hline Indonesia & 7641 & 150 & Madagascar & 61.0 & -23 \\
\hline Tanzania & 517 & 149 & Fiji & 49.2 & -23 \\
\hline Congo, DRC & 491 & 139 & Macedonia & 107 & -21 \\
\hline Paraguay & 462 & 138 & Spain & 14104 & -20 \\
\hline $\mathrm{UAE}^{a}$ & [22 755] & [136] & Slovakia & 973 & -19 \\
\hline China & [214 787] & {$[132]$} & Netherlands & 8873 & -16 \\
\hline Mozambique & 148 & 130 & Denmark & 3463 & -14 \\
\hline Liberia & 13.5 & 130 & Croatia & 755 & -14 \\
\hline
\end{tabular}

[] = SIPRI estimate; ( ) highly uncertain data; DRC = Democratic Republic of the Congo; UAE = United Arab Emirates.

${ }^{a}$ Figure is for 2014 and for change from 2006-14.

which account for around 70 per cent of government revenue. Other oil revenue-dependent countries in Africa were seemingly less affected. In North Africa, Algeria's military spending continued to increase (by 5.2 per cent) in 2015, reaching $\$ 10.4$ billion.

Chad's military expenditure rose and fell significantly in 2006-15. Oil revenues and military spending grew rapidly during the civil war, which raged from 2005 to 2009 . However, the end of the civil war and the sharp fall in oil prices led to a 66 per cent decrease in Chad's military expenditure between 2013 and 2015.

Nigeria's military expenditure fell by 2.5 per cent between 2014 and 2015, despite the ongoing military operations against Boko Haram. However, in late 2015 a government committee report on embezzlement in military procurement claimed that the committee had identified extra-budgetary 'interventions' totalling at least $\$ 6.6$ billion over the period $2007-15$. If the claim is accurate, it could mean that actual Nigerian military spending was more than 30 per cent higher than reported.

The impact of conflict on military spending was clearer in Mali, which boosted its military expenditure by 66 per cent between 2014 and 2015, and by 185 per cent between 2006 and 2015. Kenya, which has been militarily involved in the conflict in Somalia since 2011, increased its military expenditure by 22 per cent between 2014 and 2015, and by 47 per cent between 2006 and 2015. 
SIPRI is an independent international institute dedicated to research into conflict, armaments, arms control and disarmament. Established in 1966, SIPRI provides data, analysis and recommendations, based on open sources, to policymakers, researchers, media and the interested public.

\section{GOVERNING BOARD}

Sven-Olof Petersson, Chairman (Sweden)

Dr Dewi Fortuna Anwar (Indonesia)

Dr Vladimir Baranovsky (Russia)

Ambassador Lakhdar Brahimi (Algeria)

Ambassador Wolfgang Ischinger (Germany)

Professor Mary Kaldor (United Kingdom)

Dr Radha Kumar (India)

The Director

\section{DIRECTOR}

Dan Smith (United Kingdom)

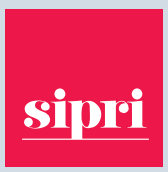

STOCKHOLM INTERNATIONAL PEACE RESEARCH INSTITUTE Signalistgatan 9 SE-169 70 Solna, Sweden Telephone: +4686559700 Email:sipri@sipri.org Internet: www.sipri.org

\section{THE SIPRI MILITARY EXPENDITURE DATABASE}

The SIPRI Military Expenditure Database provides military expenditure data by country for the years 1988-2015

- in local currency, at current prices,

- in US dollars, at constant (2014) prices and exchange rates,

- as a share (\%) of gross domestic product (GDP),

- per capita, in current US dollars, and

- as a share (\%) of general government expenditure.

SIPRI military expenditure data is based on open sources only, including a SIPRI questionnaire that is sent out annually to governments. The collected data is processed to achieve consistent time series which are, as far as possible, in accordance with the SIPRI definition of military expenditure. The database and further details on the sources and methods used are available at $<$ http://www.sipri.org/databases/milex/>.

\section{The definition of military expenditure}

Where possible, SIPRI military expenditure data includes all current and capital expenditure on

- the armed forces, including peacekeeping forces,

- defence ministries and other government agencies engaged in defence projects,

- paramilitary forces, when judged to be trained and equipped for military operations, and

- military space activities.

Such expenditure should include

- military and civil personnel, including retirement pensions of military personnel and social services for personnel,

- operations and maintenance,

- procurement,

- military research and development, and

- military aid (in the military expenditure of the donor country).

Civil defence and current expenditure on previous military activities-such as veterans' benefits, demobilization and weapon destruction-are excluded.

\section{ABOUT THE AUTHORS}

Dr Sam Perlo-Freeman (United Kingdom) is a Senior Researcher with the SIPRI Arms and Military Expenditure Programme and Head of the Military Expenditure project.

Aude Fleurant (Canada/France) is Director of the SIPRI Arms and Military Expenditure Programme.

Pieter Wezeman (Netherlands/Sweden) is a Senior Researcher with the SIPRI Arms and Military Expenditure Programme.

Siemon Wezeman (Netherlands) is a Senior Researcher with the SIPRI Arms and Military Expenditure Programme. 